\title{
IMPLEMENTASI LEAN MANUFACTURING GUNA MEREDUKSI WASTE (Studi Kasus : UD. X)
}

\author{
Nil Edwin Maitimu ${ }^{1}$, Marcy L. Pattiapon ${ }^{2}$ \\ ${ }^{1}$ Jurusan Teknik Industri, Fakultas Teknik Universitas Pattimura, Ambon \\ Email : edwinmaitimu@yahoo.com \\ 2Jurusan Teknik Industri, Fakultas Teknik Universitas Pattimura, Ambon \\ Email : marcylolita_unpatti@yahoo.com
}

\begin{abstract}
Abstrak, Tujuan akhir suatu perusahaan adalah untuk memperoleh profit setinggi mungkin. Profit yang tinggi yang akan diperoleh jika perusahaan bisa menekan sekecil mungkin pengeluaran perusahaan dan melakukan efisiensi termasuk menekan pemborosan yang ada. Untuk mencapai tujuan tersebut maka perusahaan perlu membuat proses produksi menjadi optimal. UD. X adalah salah satu perusahaan industri yang bergerak dibidang mebel. Produk yang dihasilkan oleh UD. X adalah furniture seperti meja, kursi, lemari, jendela dan pintu. Faktor yang mengakibatkan terjadinya pemborosan terhadap waktu, tenaga, jarak, material, dan mesin sehingga mengakibatkan terjadinya waktu tunggu yang lama dan memperkecil ruang gerak pekerja. Kondisi ini apabila terjadi secara terus-menerus akan berpengaruh terhadap efisiensi dan produktivitas perusahaan, yang nantinya dapat merugikan perusahaan.

Berdasarkan hasil penelitian maka urutan waste yang terjadi pada proses produksi pintu dalam UD. $\mathrm{X}$ dari rangking tertinggi sampai rangking terendah adalah waste waiting $(17,1 \%)$, waste innappropiate processing (16,5\%), waste overproduction (15,9\%), waste inventory (15,3\%), waste transportation $(14,1 \%)$ waste unnecessary motion $(11,8 \%)$ dan waste defects $(9,4 \%)$. Dengan mengetahui waste yang terjadi maka dilakukan upaya untuk mengurangi waste yang terjadi. Metode Root Cause Analysis adalah sebuah metode yang bertujuan untuk mengidentifikasi akar penyebab masalah atau peristiwa. Dengan menggunakan metode ini maka diharapakan dapat mengurangi waste yang terjadi pada sistem produksi pintu.
\end{abstract}

\section{Kata kunci: Lean Manufacturing, VALSAT, Steamlining}

\begin{abstract}
The ultimate goal of a company is to get the highest profit possible. High profit that will be obtained if the company can reduce the smallest possible company expenses and make efficiency, including reducing the waste that exists. To achieve these objectives the company needs to make the production process to be optimal. UD. $\mathrm{X}$ is one of the industrial companies engaged in furniture. Products produced by UD. $\mathrm{X}$ is furniture such as tables, chairs, cabinets, windows and doors. Factors that lead to waste of time, energy, distance, material, and machinery, resulting in a long waiting time and reduce the space for workers. This condition if it occurs continuously will affect the efficiency and productivity of the company, which in turn can be detrimental to the company.

Based on the results of the study, the sequence of waste that occurs in the door production process in UD. X from the highest ranking to the lowest ranking are waste waiting $(17.1 \%)$, waste innappropiate processing $(16.5 \%)$, waste overproduction $(15.9 \%)$, waste inventory $(15.3 \%)$, waste transportation (14, $1 \%)$ waste unnecessary motion $(11.8 \%$ ) and waste defects $(9.4 \%)$. By knowing the waste that occurs then an effort is made to reduce the waste that occurs. The Root Cause Analysis method is a method that aims to identify the root cause of a problem or event. By using this method it is expected to reduce the waste that occurs in the door production system.
\end{abstract}

Keywords: Lean Manufacturing, VALSAT, Steamlining 


\section{PENDAHULUAN}

Tujuan akhir suatu perusahaan adalah untuk memperoleh profit setinggi mungkin. Profit yang tinggi yang akan diperoleh jika perusahaan bisa menekan sekecil mungkin pengeluaran perusahaan dan melakukan efisiensi termasuk menekan pemborosan yang ada. Upaya untuk efisiensi dapat dilakukan dengan menerapkan konsep lean manufacturing. Konsep ini menekankan pentingnya efisiensi yakni pengurangan pemakaian sumber daya untuk mencapai hasil yang setidaknya sama atau mengurangi waste [9]. Lead time yang panjang merupakan salah satu bentuk waste yaitu waiting, sehingga lead time yang panjang merupakan masalah yang sangat crucial karena akan berpengaruh pada kunci kompetensi yang akan berpengaruh pada fleksibilitas dan kecepatan respon terhadap konsumen. Dengan memperpendek lead time dan memusatkan perhatian untuk memfleksibelkan jalur produksi, maka akan diperoleh kualitas yang lebih tinggi, respon terhadap konsumen lebih cepat, produktivitas lebih tinggi, dan pema nfaatan peralatan dan ruangan yang lebih baik [7].

UD. X adalah salah satu perusahaan industri yang bergerak di bidang mebel. Produk yang dihasilkan oleh UD. X adalah furniture seperti meja, kursi, lemari, jendela dan pintu. Kayu yang digunakan oleh UD. $X$ ini yaitu kayu linggua dan kayu besi yang di kirim langsung dari pulau Seram. Terdapat beberapa faktor yang mengakibatkan terjadinya pemborosan terhadap waktu, tenaga, jarak, material, dan mesin. Contohnya seperti terjadi penumpukan pada area produksi disebabkan karena kurangnya tenaga kerja sehingga menyebabkan proses produksi satu ke proses produksi berikutnya bisa memakan waktu paling lambat itu 1 minggu dan paling cepat itu 3 hari, sehingga mengakibatkan terjadinya waktu tunggu yang lama dan memperkecil ruang gerak pekerja.

Permasalahan yang diduga terjadi adalah adanya waste yang terjadi pada lini produksi UD. X Kondisi ini apabila terjadi secara terus-menerus maka akan berpengaruh terhadap efisiensi dan produktivitas perusahaan, yang nantinya dapat merugikan perusahaan. Adapun tujuan dari penulisan ini adalah mengidentifikasi dan mengevaluasi setiap waste yang terjadi pada UD. X sehingga dapat mengetahui faktor-faktor penyebab waste yang harus perlu diperbaiki

Untuk mencapai tujuan tersebut maka perlu dilakukan penerapan metode yang sesuai sangat diperlukan untuk mengidentifikasi tingkat pemborosan atau waste sehingga mampu menekan atau bahkan bisa mengurangi kegiatan atau aktivitas yang tidak memberikan nilai tambah (non value added activity).

\section{BAHAN DAN METODE}

\subsection{Konsep Lean Manufacturing}

Prinsip utama dari pendekatan lean adalah untuk mengurangi atau meniadakan pemborosan [10]. Istilah "lean" yang dikenal luas dalam dunia manufaktur dewasa ini dikenal dalam berbagai nama yang berbeda seperti: lean production, lean manufacturing, toyota production system, dan lainlain. Meskipun demikian, lean dipercaya oleh sebagian orang dikembangkan di Jepang, khususnya Toyota sebagai pelopor sistem lean manufacturing. Pengertian lean manufacturing yaitu sebuah pendekatan sistematik untuk mengidentifikasi dan meminimasi pemborosan melalui perbaikan dan pengembangan yang terus-menerus dan berkelanjutan, berusaha membuat aliran produksi menjadi lancar untuk berusaha menarik perhatian konsumen dalam upaya mencapai kesempurnaan. Beberapa alat standar untuk lean, seperti value stream mapping (VSM), produksi smoothing (Heijunka), perbaikan terus-menerus (kaizen), 5S, pertukaran mati satu menit, total manajemen kualitas, just in time, dan lain-lain, telah dikandung oleh Toyota Production System [11]. Tujuan dari lean manufacturing adalah untuk membangun dan merancang sebuah manufaktur yang mampu memproduksi beberapa produk dengan menggunakan jumlah waktu yang benar-benar dibutuhkan membuat produk. Menunggu, waktu antrian, dan penundaan lainnya dianggap pemborosan dan sangat diminimumkan atau dihilangkan dalam lean manufacturing [5].

\subsection{Understanding Waste}

Waste dapat didefinisikan sebagai segala aktivitas kerja yang tidak memberikan nilai tambah dalam proses transformasi input menjadi output sepanjang value stream. Tujuh macam waste telah diperkenalkan oleh Shiegeo Shingo [4]. Tujuh macam waste tersebut terlihat pada Gambar 1.

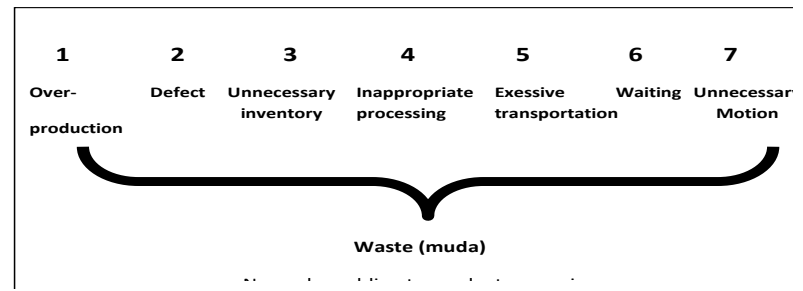




\subsection{Value Stream Mapping(VSM)}

Fokus dari VSM dibatasi pada aliran produksi di dalam pabrik. Aliran material harus diperhatikan dan pemetaan ditujukan pada satu produk sejenis [6]. VSM adalah sebuah teknik perbaikan perusahaan untuk menggambarkan seluruh proses produksi, yang meliputi aliran informasi dan material, dalam rangka meningkatkan proses produksi dan mengidentifikasi sumber pemborosan. Proses pemetaan dari current state dimulai dari awal proses produksi sampai dengan produk siap dikirim ke konsumen, dimana setiap proses dalam jalur aliran material menjadi obyek pemetaan. Intinya adalah untuk menentukan waktu yang memberikan nilai tambah dan pemborosan dari waktu yang tidak memberikan nilai tambah. Inti utama dari proses pemetaan adalah untuk menyesuaikan langkah produksi dengan permintaan, sehingga diperlukan usaha untuk membuat proses kerja seimbang dengan waktuyang tersedia.

\subsection{Big Picture Mapping}

Dalam konteks manufaktur, aplikasi konsep lean cenderung untuk memproduksi barang (lean production) yang dibutuhkan oleh kosumen, pada saat diperlukan dan dalam jumlah sesuai dengan pesanan (order) .istilah Lean Manufacturing erat hubunganya dengan big picture mapping.

Dengan big picture mapping, dapat diketahui aliran informasi dan fisik dalam sistem, lead time yang dibutuhkan dari masing-masing proses yang terjadi [12]. Tujuan dari big picture mapping adalah untuk membuat dan menyalurkan produk atau jasa kepada konsumen akhir. Rangkaian atau jaringan ini terbentang dari penambang bahan mentah (di bagian hulu) sampai retailer / toko (pada bagian hilir).

\subsection{Value Stream Mapping Tools (VALSAT)}

VALSAT merupakan tool yang dikembangkan oleh Hines \& Rich [3] untuk mempermudah pemahaman terhadap value stream yang ada dan mempermudah untuk membuat perbaikan berkenaan dengan waste yang terdapat di dalam valuestream. VALSAT merupakan sebuah pendekatan yang digunakan denganmelakukan pembobotan waste, kemudian dari pembobotan tersebut dilakukan pemilihan terhadap tool dengan menggunakan matrik.

Terdapat 7 tools yang bisa digunakan, yaitu: Process Activity Mapping, Supply Chain Response Matrix, Production Variety Funnel, Quality Filter
Mapping, Demand Amplification Mapping, Decission Point Analysis, dan Physical Structure.

\subsection{Diagram Sebab Akibat}

Diagram sebab akibat dikembangkan oleh Dr. Kaoru Ishikawa pada tahun 1943 sehingga disebut diagram Ishikawa. Diagram sebab akibat menggambarkan garis-garis dan simbol-simbol yang menunjukan hubungan antra akibat dan penyebab suatu masalah untuk selanjutnnya diambil tindakan perbaikan. Dari akibat tersebut kemudian dicari beberapa kemungkinan penyebabnya. Penyebab masalah ini pun dapat berasal dari berbagai sumber sumber utama, misalnya metode kerja alat dan bahan, pengukuran, karyawan, lingkungan dan sebagainya. Selanjutnya dari sumber-sumber diturunkan menjadi beberapa sumber yang lebih kecil dan mendetail.

\subsection{Diagram Pareto}

Diagram pareto adalah grafik batang yang menunjukkan masalah berdasarkan urutan banyaknya jumlah kejadian. Urutannya mulai dari jumlah permasalahan yang paling banyak terjadi sampai yang paling sedikit terjadi. Hal ini dapat membantu menemukan permasalahan yang paling penting untuk segera diselesaikan (rangking tertinggi) sampai dengan masalah yang tidak harus segera diselesaikan (rangking terendah) [2]. Dalam grafik, ditunjukkan dengan batang grafik tertinggi (paling kiri) hingga grafik terendah (paling kanan).Oleh karena itu diagram pareto adalah suatu gambar yang mengurutkan suatu klasifikasi data dari kiri ke kanan menurut urutan rangking tertinggi hingga terendah.

\subsection{Bussines Process Management}

Business Process Management adalah sejumlah aktivitas yang saling berhubungan, yang dapat mengubah input menjadi output yang menambah nilai dalam pandangan konsumen [1], misalnya pemenuhan order yang menjangkau semua fungsi organisasi yang dimulai dari customer order sampai final delivery.

Penggunaan Business Process management dilakukan untuk mengukur dan menganalisa proses serta melakukan perbaikan yaitu dengan mengeliminasi waste [8]. Business Process management merupakan suatu pendekatan yang sistematis untuk memahami, menganalisis, adanya support dan secara terus menerus melakukan perbaikan terhadap proses pokok seperti proses manufaktur, pemasaran, komunikasi serta unsur lainnya dalam proses operasi perusahaan. Busines 
process management rata-rata digunakan perusahaan untuk mengarahkan dan memperbaiki proses untuk mencapai sasaran.

\section{HASIL DAN PEMBAHASAN}

\subsection{Sistem Waktu Kerja dan Proses Produksi}

UD. X melakukan produksi tergantung dari permintaan konsumen, tetapi ketika tidak ada konsumen yang memesan produk, maka pekerja akan memproduksi beberapa produk untuk disimpan. Hal ini dilakukan agar mengurangi waktu menganggur pekerja disaat tidak ada pemesanan. Proses produksi setiap harinya dimulai dari pukul 09.00 WIT sampai 17.00 WIT. Proses produksi pintu pada UD. X dapat dilihat dalam gambar 2 .

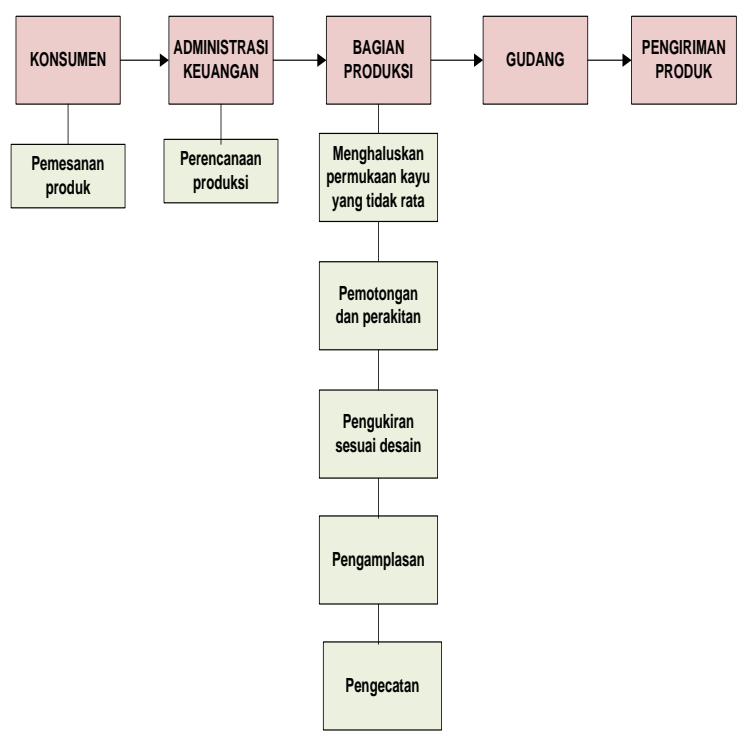

Gambar 2. Proses produksi pintu

\subsection{Big Picture Mapping (BPM)}

Big picture mapping digunakan untuk menggambarkan secara lengkap aliran proses yang meliputi aliran fisik material dan aliran informasi yang menyertainya serta lead time yang dibutuhkan dari masing-masing proses yang terjadi. Tujuan dari big picture mapping adalah untuk membuat dan menyalurkan produk atau jasa kepada konsumen akhir. Rangkaian atau jaringan ini terbentang dari penambang bahan mentah (di bagian hulu) sampai retailer / toko (pada bagian hilir).Penggambaran BPM ini bertujuan untuk lebih memahami sistem yang diamati dan untuk memudahkan dalam mencari potensi-potensi pemborosan, penyebab, akibat serta solusi yang mungkin dapat diterapkan.

\subsection{Pemilihan Tools dengan Value Stream Mapping Tools (VALSAT)}

Berdasarkan skor rata-rata dari setiap pemborosan, langkah selanjutnya adalah menentukan detailed mapping tool yang sesuai dengan jenis pemborosan yang timbul pada proses produksi. Pemilihan detailed mapping tool ini dilakukan berdasarkan perhitungan bobot pada Value Stream Analysis Tool (VALSAT). Perhitungan bobot pada VALSAT ini dilakukan dengan mengalikan bobot pemborosan yang diperoleh dari kuisioner dengan faktor pengali hubungan antara pemborosan dengan detailed mapping tool yang dipakai. Perhitungan valsat, dilakukan sesuai dengan ketetapan valsat [3]. Hasil perangkingan VALSAT dapat dilihat pada tabel 1 .

Tabel 1. Perankingan VALSAT

\begin{tabular}{|c|c|c|}
\hline Tools & $\begin{array}{c}\text { Total } \\
\text { Skor }\end{array}$ & Rangking \\
\hline $\begin{array}{c}\text { Process Activity } \\
\text { Mapping }\end{array}$ & 171.3 & 1 \\
\hline $\begin{array}{c}\text { Supply Chain } \\
\text { Response Matrix }\end{array}$ & 98.7 & 2 \\
\hline $\begin{array}{c}\text { Production Variety } \\
\text { Funnel }\end{array}$ & 31.8 & 6 \\
\hline $\begin{array}{c}\text { Quality Filter } \\
\text { Mapping }\end{array}$ & 33.5 & 5 \\
\hline $\begin{array}{c}\text { Demand } \\
\text { Amplification } \\
\text { Mapping }\end{array}$ & 66.6 & 3 \\
\hline $\begin{array}{c}\text { Decission Point } \\
\text { Analysis }\end{array}$ & 45.5 & 4 \\
\hline Physical Structure. & 8.3 & 7 \\
\hline
\end{tabular}

Berdasarkan hasil perhitungan VALSAT yang telah dilakukan, dapat dilihat bahwa tools yang dipakai untuk melakukan detail mapping adalah :

1. Process Activity Mapping, dengan nilai 171.3

2. Supply Chain Response Matrix, dengan nilai 98.7 Pemilihan ini dilakukan berdasrkan kemampuan tools dalam mengidentifikasi ketujuh jenis pemborosan (waste) yang terjadi di UD.X.

\subsection{Identifikasi Value Stream Mapping Tools}

Pada tahap ini peneliti akan menganalisa tiga tools yang memiliki hasil tertinggi. Tahap ini dapat dilakukan denga cara-cara berikut :

\subsubsection{Process Activity Mapping ( PAM )}

Berdasarkan tabel 2 maka waktu yang dibutuhkan untuk seluruh proses pada UD. X adalah 1960 menit. Dengan total aktiviktas dalam proses ini adalah sebanyak 26 aktifitas. Dari 26 aktivitas, 12 aktivitas 
merupakan aktivitas operasi, 4 aktifitas transportasi, 8 aktivitas inspeksi, 1 aktivitas strorage, dan 1 aktivitas delay.

Tabel 2. Total Presentase aktifitas VA, NVA, dan NNVA

\begin{tabular}{|c|c|c|}
\hline Aktifitas & Jumlah & $\begin{array}{c}\text { Waktu } \\
\text { (Menit) }\end{array}$ \\
\hline Operation & 12 & 825 \\
\hline Transportation & 4 & 270 \\
\hline Inspection & 8 & 40 \\
\hline Storage & 1 & 705 \\
\hline Delay & 1 & 120 \\
\hline VA & 10 & 675 \\
\hline NVA & 12 & 895 \\
\hline NNVA & 4 & 390 \\
\hline TOTAL & \multicolumn{2}{|c|}{34.44} \\
\hline $\begin{array}{c}\text { WAKTU } \\
\text { (minute) }\end{array}$ & \multicolumn{3}{|c|}{45.66} \\
\hline \%VA & \multicolumn{3}{|c|}{19.90} \\
\hline \%NVA & \multicolumn{3}{|c|}{} \\
\hline \%NNVA & \multicolumn{3}{|c|}{} \\
\hline
\end{tabular}

\subsubsection{Pembuatan Supply Chain Response Matrix (SCRM)}

Supply Chain Response Matrix (SCRM) merupakan sebuah grafik yang menggambarkan hubungan antara inventory dengan lead time (ranges waktu yang diperlukan hingga produk jadi) yang dapat dipergunakan untuk mengidentifikasi dan mengevaluasi kenaikan dan penurunan tingkat persediaan dan panjang lead time pada tiap area dalam supply chain. Gambar 3 merupakan grafik SCRM.

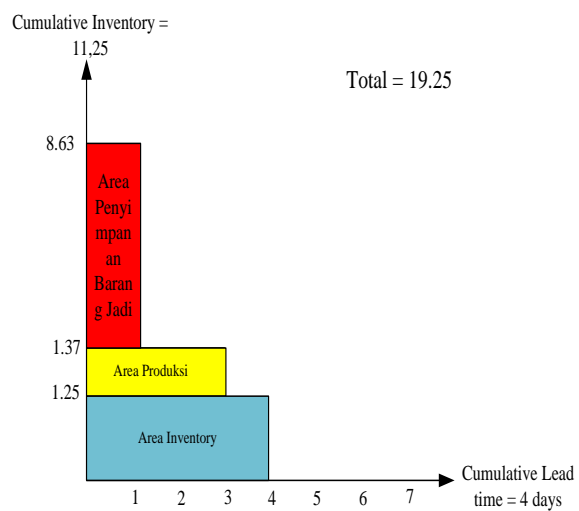

Gambar 3. Grafik suplly chain
Dari grafik diatas terlihat bahwa lead time rantai supply dalam area produksi adalah selama 11 hari. Sedangkan lamanya penyimpanan dalam sistem adalah 11,25 hari jadi total waktu respon supply dalam sistem adalah sebanyak 15.25 hari. Tergambar bahwa proses penyimpanan bahan baku menghasilkan lead time yang paling besar hal ini berbanding lurus dengan inventory yang ada pada sistem yang menyebabkan perusahaan harus membuat produk selama 2 hari dalam proses activity mapping. Dalam PAM akan tergambar juga bahwa jenis pemborosan inventory adalah yang memiliki kontribusi tersbesar.

\subsection{Perbaikan Proses (Improvement Process)}

Untuk memberikan tingkat kepuasan yang lebih tinggi pada konsumen maka perusahaan harus memperbaiki proses bisnis yang ada pada perusahaan sehingga tujuan untuk memberikan kepuasan pada konsumen akan menjadi lebih baik. Sasaran dari setiap organisasi adalah melakukan perbaikan terhadap semua kegiatan sehingga dapat memberikan nilai tambah bagi konsumen. Dalam merancang ulang proses pemenuhan order yang telah ada pada perusahaan maka penekanannya adalah pada mengeliminasi kegiatan yang tidak memberikan nilai tambah.

Prinsip streamlining adalah mengeliminasi waste, yang mendorong kearah improvement dan kualitas. Dengan menggunakan pendekatan streamlining maka akan memperlancar aliran, mencapai tujuan dengan usaha yang minimum. Berdasarkan prinsip streamlining maka didalam melakukan perbaikan dapat diringkas sebagai berikut :

- Mengeliminasi (eliminate)

- Value-Added Assessment (VAA)

Berdasarkan informasi dari pihak perusahaan dan pengamatan dilapangan maka perbaikan yang dilakukan pada proses pembuatan pintu saat ini difokuskan pada proses manufaktur. Hal ini disebabkan karena dalam proses produksi sering terjadi bottleneck yang diakibatkan karena keterbatasan sumber daya berupa mesin dan operator yang digunakan dalam proses produksi. Untuk itu perlu dilakukan penambahan sumber daya berupa mesin dan operator sehingga proses produksi dapat berjalan dengan lancar yang pada akhirnya dapat memberikan kepuasan kepada konsumen.

\subsection{Analisa Waste Overproduction}

Waste overproduction merupakan pemborosan terhadap produk yang produksi melebihi dari jumlah yang dibutuhkan yang mengakibatkankan terjadinya 
penumpukan, inventory yang berlebihan serta terganggunya aliran informasi dan material. Dapat dilihat pada gambar 4 .

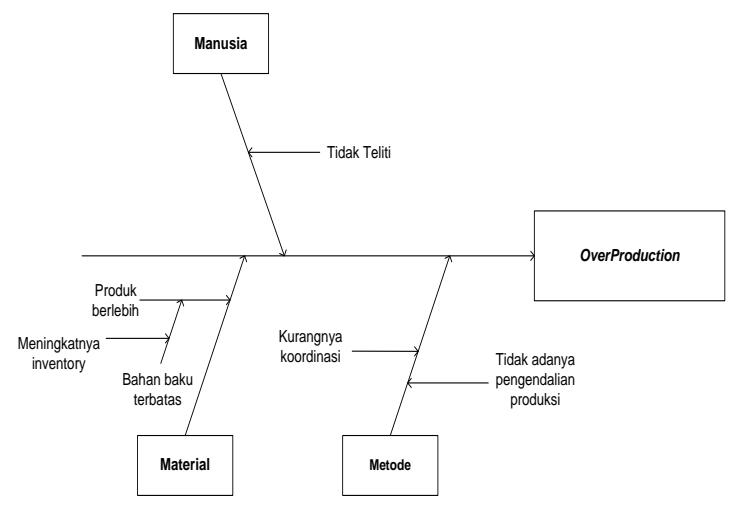

Gambar 4. Fishbone penyebab waste overproduction

\subsection{Analisa Waste Waiting}

Waiting merupakan salah satu jenis pemborosan, dikarenakan waiting adalah suatu jenis pemborosan terhadap penggunaan waktu yang kurang efisien. Jenis waste ini disebabkan oleh pekerja menunggu produk untuk diproses ataupun sebaliknya. Dapat dilihat pada gambar 5

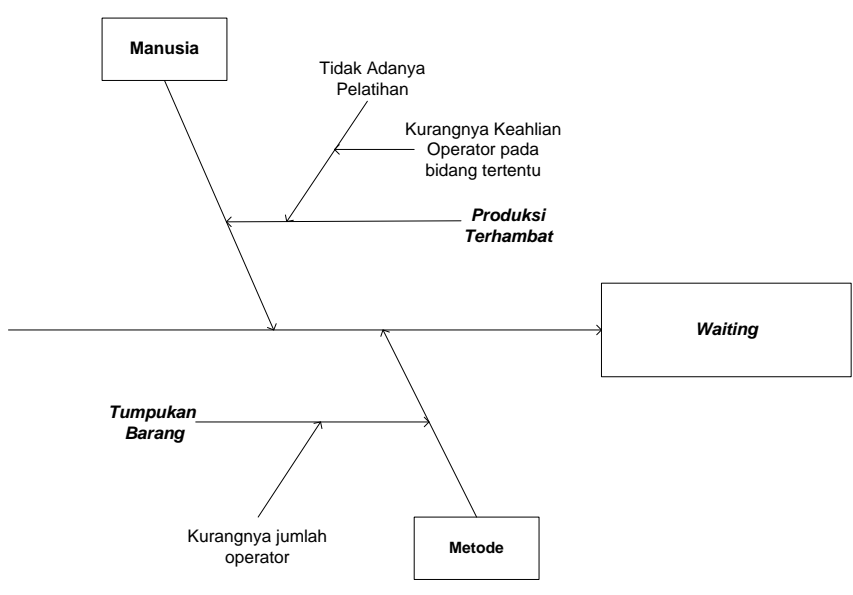

Gambar 5. Fishbone penyebab waste waiting

\subsection{Analisa Waste Transportation}

Waste transportation adalah suatu jenis waste yang disebabkan oleh proses perpindahan yang tidak memiliki nilai tambah, baik manusia maupun material yang menyebabkan kerugian terhadap waktu, biaya, dan tenaga. Dapat dilihat pada gambar 6.

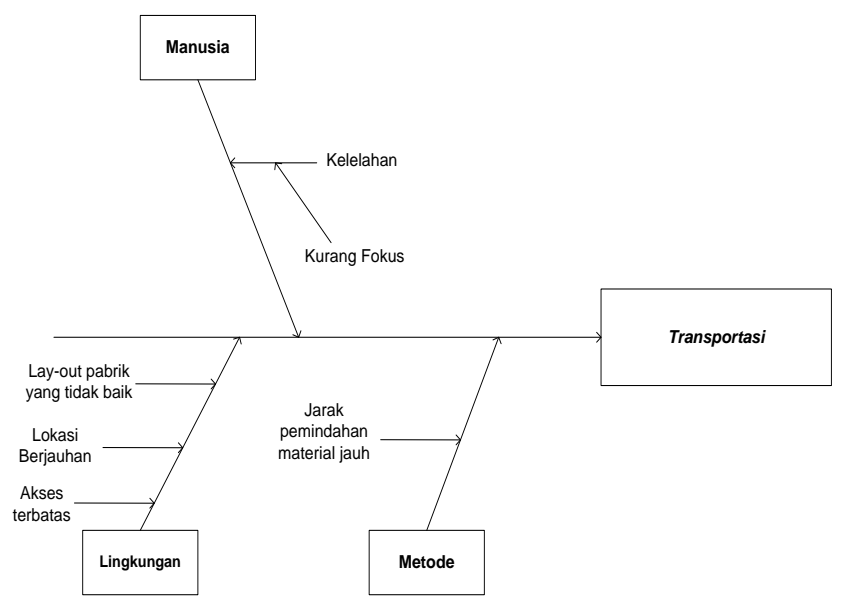

Gambar 6. Fishbone penyebab waste transportation

\subsection{Rekomendasi Perbaikan}

Berdasarkan penjelasan diatas mengenai jenisjenis pemborosan yang terjadi pada UD. $\mathrm{X}$ beserta dampak dari setiap pemborosan yang timbul, maka untuk langkah selanjutnya yang akan dilakukan adalah membuat rekomendasi atau perbaikan atas permasalahan yang terjadi dalam upaya meminimalisasikan pemborosan yang terjadi di lantai produksi di UD. X.

Rekomendasi perbaikan akan dilakukan berdasarkan hasil penggambaran pemborosan pada whole stream sistem produksi, hasil analisa.

\section{KESIMPULAN}

Berdasarkan hasil penelitian yang telah dilakukan pada UD. X dapat disimpulkan sebagai berikut :

1. Pada UD. X terdapat tujuh pemborosan yang dapat diidentifikasi sesuai dengan konsep seven waste yaitu Overproduction, Waiting, Transportation, Innappropiate Processing, Inventory, Unnecessary Motion, Defects. Dimana dalam mengidentifikasi setiap jenis waste yang terjadi pada lantai produksi ditemukan beberapa faktor yang menyebabkan terjadinya waste berdasarkan ketujuh jenis waste tersebut. Dari hasil waste workshop yang dilakukan dengan menggunakan kuesioner yang disebarkan dan wawancara yang dilakukan pada UD. X, diketahui bahwa pemborosan yang terjadi diurutkan mulai dari terbesar sampai terkecil tingkat pemborosannya adalah sebagai berikut : 
- Overproduction

- Waiting

- Transportation

- Inappropiate Processing

- Unnecessary Inventory

- Unnecessary Motion

- Defect

2. Berdasarkan hasil penelitian yang telah dilakukan pada UD X dan telah melalaui proses analisa dan pembahasan yang telah dilakukan oleh peneliti pada penulisan saat ini. Dalam penelitian ini, berdasarkan hasil perhitungan VALSAT, maka tools yang dipakai adalah Process Activity Mapping denngan total skor yang diperoleh adalah 171.3 dan tools Supply Chain Response Matrix dengan total skor 98.7. dimana dengan tools ini akan mempermudah peneliti untuk mengidentifikasi setiap jenis waste yang terjadi di lantai produksi secara detail, agar dapat memberikan rekomendasi perbaikan proses di lantai produksi.

Pada PAM teridentifikasi bahwa terdapat 26 jenis aktifitas yang terjadi pada lantai produksi, dimana setiap aktifitas bisa dikategorikan sebagai aktifitas yang memberikan nilai tambah (Value Added), aktifitas yang tidak memberikan nilai tambah (Non Value Added), dan aktifitas yang tidak memberikan nilai tambah tapi diperlukan (NNVA). Dengan total waktu untuk seluruh aktifitas produksi (lead time) adalah 1960 menit dengan total presentase untuk VA adalah $34.44 \%$, NVA (45.66\%) dan NNVA (19.90\%).

\section{DAFTAR PUSTAKA}

[1] Al-Mudimigh A. S, The role and impact of business process management in enterprise systems implementation. Business Process Management Journal. Vol. 13 No. 6, pp. 866-874, 2007.

[2] Ariani, Dorothea) "Pengendalian Kualitas Statistik (Pendekatan Kuantitatif dalam Manajemen Kualitas)" Edisi Satu. Penerbit: ANDI OFFSET, Yogyakarta, 2004.

[3] Hines, P. dan Rich, N, The seven value stream mapping tools. International Journal of Operations \& Production Management, Vol. 17 No. 1, pp. 46-64, 1997.

[4] Hines, P. dan Taylor, D, Going Lean: a guide to implementation. Lean Enterprise Research Center, Cardiff Bussiness School, USA, 2000.
[5] Hobbs, Tujuan Dari Lean Manufacturing, 2008

[6] Kalsaas. Value Stream Mapping (VSM), 2020.

[7] Liker, J. K. (2006), The Toyota Way. Erlangga, Jakarta, 2006.

[8] Lee, R.G. dan Dale, B.G. (1998), Business process management: a review and evaluation. Business Process Management Journal, Vol. 4 No. 3, pp. 214-225

[9] Pujawan, I Nyoman., Supply Chain Management. Guna Widya, Surabaya, 2005.

[10] Pujawan.. Prinsip Utama Dari Pendekatan Lean.2002

[11] Sahoo, \& dkk.. Toyota Production System, 2007.

[12] Shingo. 7 Tipe-Tipe Pemborosan. Tjiong, W. S., \& L, M.. Big Picture Mapping, 2011. 